\title{
Dialog dzieci i nauczycieli w żłobkach Reggio Emilia
}

\begin{abstract}
Abstrakt
Artykuł przedstawia podejście Reggio Emilia w kontekście doświadczeń edukacyjnych najmłodszych dzieci. Od początku istnienia tego projektu żłobki postrzegane są jako miejsce edukacji, w którym dzieci, wchodząc w relacje z innymi, konstruują swoją własną wiedzę. W procesie tym kluczową rolę odgrywa nauczyciel, którego zadaniem jest przede wszystkim słuchanie, obserwowanie i zrozumienie strategii, jakich dzieci używają w trakcie uczenia się. Relacja dziecko - nauczyciel została zilustrowana fragmentami dokumentacji projektów realizowanych w żłobkach Reggio Emilia.
\end{abstract}

Słowa kluczowe: żłobek, Reggio Emilia, metoda projektów, profil nauczyciela żłobka.

\section{The dialogue between children and teachers in Reggio Emilia infant-toddler centers}

\begin{abstract}
The article presents the Reggio Emilia approach in the context of educational experiences of the youngest children attending infant-toddler centers. From the very beginning, these institutions have been seen as a place of education, where children construct their own knowledge along with adults. From this point of view, the role of the teacher is crucial and his main task is above all listening, observing and understanding the strategy that the children use in learning situations. The relationship between children and teachers has been illustrated with excerpts of documentation of projects carried out in infant-toddler centers in Reggio Emilia.
\end{abstract}

Keywords: infant-toddler center, Reggio Emilia, project approach, infant/toddler teacher's profile.

\footnotetext{
* Uniwersytet Łódzki, Wydział Nauk o Wychowaniu, Katedra Pedagogiki Wieku Dziecięcego, Zakład Badań nad Dzieckiem i Dzieciństwem.
} 


\section{Instytucje dla małych dzieci w Reggio Emilia}

Podejście edukacyjne Reggio Emilia (dalej RE) jest obecnie jednym z najpopularniejszych rozwiązań edukacyjnych w zakresie wczesnej edukacji na świecie. Odnosi się ono do doświadczeń miejskich żłobków i przedszkoli w Reggio Emilia we Włoszech (Scuole e Nidi di'Infanzia del Comune di Reggio Emilia) ${ }^{1}$, które to instytucje od początku swojego istnienia stanowią spójny system edukacji dla dzieci w wieku od 3 miesięcy do 6 lat.

Inicjatorem i liderem tego doświadczenia był charyzmatyczny pedagog Loris Malaguzzi (1920-1994). Między innymi dzięki jego inicjatywie w roku 1963 zostało otworzone pierwsze miejskie przedszkole, dając początek trwającemu do dziś projektowi wczesnej edukacji w Reggio Emilia. Kolejne lata to okres intensywnej pracy nad koncepcją pedagogiczną placówek dla najmłodszych dzieci, która w roku 1971 zaowocowała powstaniem pierwszego miejskiego żłobka (asilo nido). Podkreślenie spójności i ciągłości pomiędzy tymi dwiema instytucjami nastąpiło rok później, wraz z przyjęciem dokumentu Regolamento delle scuole comunali dell'infanzia - regulaminu miejskich placówek wczesnej edukacji, w którym zawarto kluczowe i wspólne dla żłobków i przedszkoli zasady funkcjonowania (Moss $2012 b)^{2}$.

Choć w polskich publikacjach, poświęconych podejściu RE przebija się głównie perspektywa przedszkola, to opisane idee i wartości są wspólne i charakteryzują również pracę w żłobkach (niewielkie różnice wynikają jedynie z organizacji pracy placówek). Przedstawione w niniejszym tekście założenia dotyczące pracy placówek Reggio, w tym rola nauczyciela, zostały już opisane w innych publikacjach i będą raczej swoistym przypomnieniem i podsumowaniem (zob. Maj 2011; Karwowska-Struczyk 2012; Szczepska-Pustkowska 2013). To, co dla polskiego czytelnika, mam nadzieję, okaże się ciekawe, to przedstawienie ich z perspektywy funkcjonowania żłobków i w kontekście procesu uczenia się dzieci do lat 3.

Od samego początku celem działania placówek wczesnej edukacji RE było nie tylko zapewnienie dzieciom opieki, ale również stworzenie im jak najlepszych warunków dla uczenia się. Z takiej perspektywy żłobek postrzegany jest jako

\footnotetext{
1 Obecnie sieć miejskich placówek wczesnej edukacji w Reggio Emilia obejmuje 12 żłobków przeznaczonych dla dzieci w wieku od 3 miesięcy do 3 lat oraz 21 przedszkoli przeznaczonych dla dzieci w wieku od 3 do 6 lat. Placówkami tymi zarządza Istituzione. Jest to powołana specjalnie do tego celu komórka miasta, posiadająca autonomię dydaktyczną, pedagogiczną, administracyjną oraz własny budżet, której władze nominowane są przez burmistrza miasta. Dodatkowo na mocy porozumień z Istituzione do sieci placówek włączone są żłobki i przedszkola prowadzone przez różne organizacje i stowarzyszenia ( 6 żłobków i 8 żłobków/przedszkoli). Opisując podejście edukacyjne Reggio, odnoszę się więc do doświadczeń z wyżej wymienionych placówek. Poza nimi w Reggio Emilia działa jeszcze 14 przedszkoli państwowych, 4 prywatne oraz 20 prowadzonych przez organizację katolicką FISM (http://www.scuolenidi.re.it/MappaAsiliScuole.jsp?mappa=0 [27.04.2017 r.]).

2 Zasady te pozostają aktualne po dziś dzień. Syntetyczne omówienie podstaw działania placówek wczesnej edukacji w RE zawartych w aktualnym regulaminie można znaleźć w pracy Maj (2016).
} 
miejsce edukacji ${ }^{3}$, miejsce, $\mathrm{w}$ którym dzieci, wchodząc $\mathrm{w}$ relacje $\mathrm{z}$ innymi, konstruują swoją własną wiedzę. Zadaniem instytucji dla małych dzieci staje się wówczas dostarczenie im narzędzi i zasobów niezbędnych w procesie negocjowania i nadawania znaczeń (Dahlberg i in. 2013). Wielokrotnie na potrzebę zmiany i konieczność redefinicji roli żłobków wskazywał L. Malaguzzi (2012a). W jednym ze swoich wykładów podkreślał:

W mojej opinii tym, co dzisiaj jest nam potrzebne, jest podjęcie próby nadania żłobkowi tożsamości o charakterze filozoficznym, jeśli wolicie ideologicznym; o charakterze pedagogicznym i kulturowym, gdzie żłobki zakładane są nie jako instytucja mająca na celu opiekę i zastępowanie rodziny, przynajmniej nie tylko, ale jako instytucja, która podejmuje się zadania uczestniczenia i współuczestniczenia w edukacji dzieci świadomie i z niezbędnym poczuciem odpowiedzialności (tamże: 315-316).

Przez lata L. Malaguzzi towarzyszył nauczycielom w rozwijaniu projektu edukacyjnego RE, inspirował do refleksji oraz poszukiwania nowych rozwiązań. Placówki RE stały się forum dyskusji na temat uczenia się małych dzieci, w której uczestniczyli zarówno nauczyciele, rodzice, jak i same dzieci. Projekt RE opiera się bowiem na strategii partycypacji, która zakłada współuczestniczenie 3 protagonistów. Oznacza więc nie tylko branie udziału w czymś, ale „bycie częścią czegoś istotą, treścią wspólnej tożsamości, oznacza «my», które poprzez partycypację urzeczywistnia się" (The Charter... 2002: 8). Dzieci doświadczają jej poprzez aktywne konstruowanie wiedzy, nadawanie i negocjowanie znaczeń, dla dorosłych natomiast partycypacja oznacza gotowość do zaangażowania się w projekt oraz nieustający dialog, poprzez który edukatorzy i rodzice wspólnie, będąc uważnym na codzienne edukacyjne działania, opracowują wskazówki dla polityki wczesnej edukacji i budują tym samym kulturę dzieciństwa (tamże). Wspomina o tym Carlina Rinaldi (2001):

Dla nas w Reggio, żłobki są miejscem życia dzieci, nauczycieli, rodziców - miejscem, którego celem jest nie tylko przekazywanie kultury i wspieranie rodzin, ale tworzenie nowej kultury, kultury dzieciństwa, kultury dziecka; są miejscem, w którym oferujemy społeczeństwu nową wizję dziecka, nową wizję dzieciństwa, nową wizję nauczyciela oraz nową wizję rodziny (tamże: 54).

Zmiana myślenia o charakterze żłobka wynika więc przede wszystkim z przyjętej przez nauczycieli Reggio konstrukcji dziecka i dzieciństwa. Wpływa również na nauczycielską tożsamość, zmusza do przeredefiniowania roli nauczyciela i determinuje każde podejmowane przez niego rozwiązania edukacyjne.

\footnotetext{
${ }^{3} \mathrm{~W}$ związku z takim podejściem, dorośli pracujący w żłobkach to nauczyciele (ew. edukatorzy), a nie jedynie opiekunowie czy wychowawcy.
} 


\section{Silne dziecko - silny nauczyciel}

Jak współcześnie definiują podejście RE sami edukatorzy, jest to „filozofia edukacyjna opierająca się na wizji dziecka, i człowieka, posiadającego ogromne możliwości rozwoju, będącego podmiotem praw, który uczy się i rozwija w relacji z innymi" (Reggio Emilia Approach...). Dla zrozumienia idei pracy w żłobkach, w tym roli nauczyciela i sposobu budowania jego relacji z dzieckiem, niezbędne jest więc przyjęcie optyki dziecka silnego, pełnego potencjału, dziecka, które, jak podkreśla C. Rinaldi (2001), doświadcza świata i czuje się jego częścią już od chwili narodzin. To dziecko, które ma w sobie pragnienie i zdolność komunikowania się, potrafi nadawać kierunek swojemu społecznemu, poznawczemu, emocjonalnemu rozwojowi. Nawet tak małe dziecko jak to uczęszczające do żłobka uznawane jest za kompetentne, posiadające własne strategie uczenia się oraz zdolności i sposoby budowania relacji (tamże). Dziecko postrzegane jest jako badacz, współpracownik, uczestnik procesu komunikacji (Cadwell 2003) oraz współtwórca wiedzy, tożsamości i kultury (Dahlberg i in. 2013).

Ilustracją takiej wizji małego dziecka, jednocześnie swoistą wizytówką podejścia edukacyjnego Reggio, jest doświadczenie Laury, rocznej dziewczynki uczęszczającej do jednego ze żłobków w Reggio4. Epizod z zegarkiem, zapewne najczęściej przedstawiany przez edukatorów Reggio, ukazuje dziecko będące konstruktorem swojej własnej wiedzy, dziecko, które, przy wsparciu dorosłych gotowych słuchać, obserwować i towarzyszyć mu, jest w stanie stawiać hipotezy dotyczące otaczającego świata i weryfikować je. Poniższy fragment, pochodzący z pamiętnika Laury zawiera opis jej doświadczeń widzianych oczami nauczycielki Elluci Forghnieri. W pamiętniku nauczycielska narracja została uzupełniona serią zdjęć, które krok po kroku ilustrują doświadczenie Laury z zegarkiem ${ }^{5}$.

Po jedzeniu, przy stole. Wszyscy są bardzo szczęśliwi. Dzieci bawią się ze sobą i „rozmawiają”. Korzystając ze spokoju, daję Laurze duży katalog pełen zdjęć i zachęcam do przejrzenia go. Podczas oglądania jest bardzo skupiona, przy-

\footnotetext{
${ }^{4}$ Laura (ur. 13.10 .1980 r.) zaczęła uczęszczać do żłobka „Arcobelano” w Reggio Emilia we wrześniu 1981 r., w wieku 10,5 miesięcy. Jej doświadczenie (podobnie jak każdego innego dziecka) zostało opisane w indywidualnym pamiętniku prowadzonym przez nauczycielki. W $1983 \mathrm{r}$. został on opublikowany w Quderni Reggiani - specjalnie wydanej przez miasto publikacji, której celem było przedstawienie społeczności lokalnej koncepcji pedagogicznej pracy w żłobkach RE. Jego przedruk i tłumaczenie ukazało się w książce The Diary of Laura. Perspectives on a Reggio Emilia Diary (Edwards, Gandini 2009).

5 Ze względu na prawa autorskie nie ma możliwości umieszczenia tych zdjęć w tekście. Seria zdjęć składała się z 6 ujęć: 1 - Nauczycielka i Laura siedzą przy stoliku, Laura przewraca kartki w katalogu, katalog otwarty jest na stronie, na której widać dwie ludzkie postaci, 2 - Laura przygląda się stronom w katalogu z zegarkami, jest lekko nachylona w stronę nauczycielki, 3 - Laura skierowana twarzą w stronę nauczycielki, patrzy na nią i wskazuje palcem na jeden z zegarków, 4 - Nauczycielka wystawia rękę z zegarkiem, Laura dotyka go i obserwuje, 5 - zbliżenia: Laura przykłada ucho do zegarka nauczycielki, 6 - zbliżenie: Laura przykłada ucho do strony z zegarkami w katalogu.
} 
gląda się każdemu zdjęciu z zainteresowaniem, nie odwracając od niego wzroku. Gdy przewraca strony, jej ruchy są bardzo ostrożne i precyzyjne.

Nie wtrącam się, żeby jej nie przeszkadzać - jest taka skupiona. Obserwuję ją. Mówiąc cicho „mama”, „tata”, wskazuje na wizerunki mężczyzn i kobiet.

Przed nią rząd zegarków, patrzy na mnie; przybliżam się i patrzę na nią. Pokazując jej ten na moim nadgarstku, mówię: „To są zegarki”. Przykładam zegarek blisko jej ucha, tak aby mogła usłyszeć jego tykanie. Słucha przez dłuższy czas w skupieniu, potem odsuwa ucho; podnosi głowę, wraca do zdjęć, patrzy na nie ponownie, a następnie pewna siebie przykłada swoje ucho do strony w katalogu. (Ellucia) (The Diary... 2009: 51).

Z tego krótkiego epizodu wyłania się obraz dziecka, którego źródeł możemy szukać w teoriach konstruktywizmu. Z jednej strony doświadczenie to może być egzemplifikacją piagetowskiego procesu adaptacji, z drugiej zaś dostrzec można interakcyjną orientację w konstruowaniu znaczeń. Choć w narracji i na zdjęciach dominuje dziecko, obecność nauczyciela nie jest bez znaczenia, jest on częścią relacji i towarzyszy dziecku w procesie uczenia się.

Dla edukatorów Reggio, w tym dla L. Malaguzziego, jednym z niezwykle znaczących źródeł inspiracji była teoria J. Piageta. Krytyczny namysł połączony z wnikliwą obserwacją dzieci doprowadził ich jednak do rewizji swoich poglądów na temat dziecięcego procesu uczenia się. W wywiadzie z Lellą Gandini L. Malaguzzi przyznał, że „teraz jasno widzimy, jak teoria Piageta izoluje dziecko” (Gandini 2012: 56). Krytyce poddał m.in. niedocenianie roli dorosłego w rozwoju poznawczym dziecka, marginalizowanie roli interakcji społecznych i związku pomiędzy myśleniem a językiem, dominujące znaczenie myślenia logiczno-matematycznego oraz nadużywanie paradygmatu wywiedzionego $\mathrm{z}$ nauk ścisłych (tamże). W takim kontekście interpretacji obserwowanych dziecięcych doświadczeń edukatorzy Reggio poszukiwali w myśli Lwa Wygotskiego. L. Malaguzzi, nazywając go „naszym Wygotskim” (tamże: 58), podkreślał, że przypomniał on, jak ważną rolę w rozwoju i uczeniu się odgrywa język ${ }^{6}$ i umiejętność posługiwania się nim oraz „powiedział nam o zaletach strefy najbliższego rozwoju, która jest odległością pomiędzy poziomem wyrażonym przez dziecko a poziomem potencjalnego rozwoju, osiągniętego z pomocą dorosłych lub bardziej zaawansowanych rówieśników" (tamże). L. Wygotski, który podobnie jak J. Piaget postrzegał dziecko jako aktywnego konstruktora swojej wiedzy, akcentował jednak nie tyle kontakt dziecka z otoczeniem fizycznym, co kontekst społeczny, w którym proces uczenia się zachodzi. Interakcyjny charakter procesu uczenia się stał się bardzo ważnym elementem w placówkach Reggio. Według nauczycieli RE dziecko posiada wrodzoną umiejętność komuniko-

\footnotetext{
${ }^{6} \mathrm{~W}$ podejściu RE język rozumiany jest znacznie szerzej niż tylko język werbalny. Edukatorzy RE posługują się metaforą „100 języków dziecka” (zob. Maj 2017).
} 
wania się i już od chwili narodzin jest istotą społeczną zdolną nawiązywać relacje z innymi (Rinaldi 2012).

Przyjęta przez edukatorów Reggio wizja dziecka silnego, pełnego potencjału wymaga nauczyciela równie silnego, „wówczas szkoła staje się miejscem prowadzenia badań, w którym dzieci wraz z nauczycielami są głównymi badaczami” (tamże: 125). Z tej perspektywy zawodowa tożsamość nauczyciela nie może być rozpatrywana $\mathrm{w}$ izolacji jako abstrakcyjne pojęcie. Musi być ona interpretowana w kontekście relacji nauczyciela z innymi: współpracownikami (zob. Maj 2011), rodzicami (zob. Maj 2016) i przede wszystkim dziećmi. Wchodząc w relacje $\mathrm{z}$ innymi, nauczyciel, będąc ciekawym świata i rezygnując z biernej roli realizatora gotowych koncepcji, staje się konstruktorem wiedzy, twórcą teorii i kreatorem kultury w placówkach dla małych dzieci. Prowadzi z dziećmi intelektualny dialog, tworząc jak najlepsze warunki dla dziecięcego procesu uczenia się, co zostanie rozwinięte w dalszej części tekstu.

\section{Słuchanie jako fundament pracy nauczyciela}

Praca nauczycieli w żłobkach Reggio Emilia wymaga specyficznego podejścia do życia, które przejawia się przede wszystkim w słuchaniu. Słuchanie, które interpretowane jest przez edukatorów znacznie szerzej niż proces fizjologiczny, stanowi swoisty fundament wszystkich działań podejmowanych przez dorosłych w żłobkach RE. C. Rinaldi (2009) podejście to nazywa „aktem miłości” (tamże: 65). Oznacza bycie uważnym i otwartym na innych, na przyjmowaniu różnych punktów widzenia, akceptowaniu różnic i traktowaniu ich jako zasób, a nie przeszkodę. Wymaga używania różnorodnych języków i kodów, nie ogranicza się bowiem jedynie do języka mówionego, co jest szczególnie istotne w relacji z małymi dziećmi, które bardzo często nie zdołały jeszcze opanować, tak powszechnie używanego przez dorosłych, kodu werbalnego. Słuchanie to wrażliwość na potrzeby innych, to dawanie czasu, który jest czymś więcej niż czasem zegarowym, jest czasem wewnętrznym, pełnym ciszy i spokoju (tamże).

Taka postawa charakteryzowała również nauczycielkę Laury. Choć w każdym z jej wspomnień dostrzec można uważność i wrażliwość na potrzeby dziewczynki, z wielu opisanych w pamiętniku wspólnych doświadczeń wybrałam epizod „Trudności podczas zmiany pieluchy", który miał miejsce w okresie adaptacji dziecka. W pamiętniku Laury możemy przeczytać:

Dzisiaj znowu trudności podczas zmiany pieluchy. Aby za bardzo nie zasmucić dziecka, próbuję mnóstwo razy. Gdy próbuję położyć Laurę na przewijaku, podobnie jak wczoraj, napina się. Podnoszę ją, przytulam i jeszcze raz próbuję, ale gdy kolejny raz sztywnieje i prawie zaczyna płakać, podnoszę ją i wracamy do sali. Wziąwszy pod uwagę, że Laura jest cała mokra, po chwili próbuję znowu. 
Próbuję być bardziej delikatna. Pozwalam jej siedzieć na przewijaku i rozmawiam z nią. Pokazuję jej zabawkę. Podnoszę Laurę i zdejmuję jej spodnie. Myję ją, używając mokrych chusteczek i po chwili próbuję położyć na przewijaku. Dziecko chwyta brzeg stołu, odrobinę lżej niż poprzednio, ale wciąż w napięciu.

Trzymając ją blisko, podążam za nią moim ciałem, patrzę na nią, mówię do niej cicho. Powoli kładę, Laura odpręża się i zaczyna zwracać uwagę na moje okulary. (Eluccia) (The Diary... 2009: 35).

Fragment ten zaskoczył i poruszył mnie szczególnie, gdyż nawet przy takiej często rutynowej i mechanicznej czynności, jaką jest zmiana pieluchy, nauczycielka zaakceptowała rytm i czas dziecka, zupełnie inny niż dorosłych. Była pełna empatii i słuchała nie tylko uszami, ale i wszystkimi zmysłami. Wychwyciła moment, w którym Laura była gotowa zaakceptować wykonywanie dobrze znanej czynności, w nowych warunkach i przez nową osobę. Pozwoliła, aby relacja ta rozwijała się we własnym tempie i z własną dynamiką.

Słuchanie odgrywa też ważną rolę w procesie uczenia się. Nie tyle daje odpowiedź, co inspiruje nauczycieli do stawiania pytań. Nawet jeśli wiąże się to z niepewnością, czy rodzi frustrację lub niepokój, wymaga gotowości na doświadczanie kryzysów i przyjmowanie zmian będących ich konsekwencją. Słuchanie wymaga od nauczycieli świadomości, że ich interpretacje rzeczywistości są jednymi z możliwych i stanowią cząstkę rozległej, zintegrowanej wiedzy, przy jednoczesnym zawieszeniu własnych osądów i przekonań (Rinaldi 2009). Ta otwartość jest kluczowa w pracy z małymi dziećmi. Nauczyciel musi być uważny na dziecko, ciekawy jego pomysłów. Słuchanie polega bowiem na obserwowaniu i interpretowaniu dziecięcych działań, a w konsekwencji na inspirowaniu oraz podtrzymywaniu nowych. Niejednokrotnie wymaga to modyfikacji bądź zmiany nauczycielskich planów i propozycji. Te, przez edukatorów Reggio są traktowane jedynie jak hipotezy, jako możliwe kierunki dziecięcej aktywności. Nauczyciele organizują przestrzeń, są ciekawi, jakie przyniesie możliwości. Takie podejście ilustruje poniższy przykład.

Nauczycielka przekształciła przestrzeń w żłobku, pokrywając całą podłogę dużymi pasami zwijającego się papieru. W opisanym doświadczeniu uczestniczyła trójka dzieci Erika (13 m-cy), Elisabetta (11 m-cy) i Matteo (10 m-cy).

Matteo, Erika, Elisabetta siedzą na papierze, którym przykryta jest cała podłoga w sali. Matteo trzyma mazak, który wcześniej podniósł z podłogi (mazaki w różnych kolorach pozostawione były przez nauczycieli po to, aby dzieci, jeśli chcą, mogły ich użyć do rysowania na dużym papierze). Teraz dzieje się coś niespodziewanego. Matteo, z pomocą Elisabetty, ciągnie za róg papieru...

... dopóki kawałek papieru nie odrywa się. Urwany kawałek zwija się,... tworząc tubę. 
Gra zaczyna być bardzo interesująca. Matteo, trzymając mazak w ręku, uważnie obserwuje nową „tubę”, po czym chwyta ją drugą ręką...Sprawia wrażenie jakby zauważył możliwą relację pomiędzy mazakiem a tubą.

Napięcie mięśni i koncentracja Matteo wzrasta; podnosi tubę, lekko ją przechyla, przygląda się otworowi i próbuje wsunąć mazak do środka. Jego wysiłek powoduje, że przechyla tubę za bardzo i jego próba okazuje się nieudana. [...]

Erika, obserwując go z boku, choć z pozornym brakiem zainteresowania, przesuwa się w kierunku Matteo. Być może zrozumiała cel „manewrów” Matteo?

Erika bierze tubę i drugi mazak, obserwuje go uważnie i zdecydowanie wsuwa mazak do tuby. Matteo odwraca spojrzenie w drugą stronę, tak jakby był zawiedziony lub zdenerwowany.

[...] Erika pewnie spogląda na dół tuby, sprawia wrażenie jakby na coś czekała, prawdopodobnie na mazak, który ma wylecieć, nic tam jednak nie ma! Ponieważ tuba jest przechylona za lekko, mazak utyka w środku. Co robić? Porzucić starania? Po chwili...

Erika, bacznie i z ciekawością obserwowana przez Elisabettę, mocno chwyta drugi mazak i wsuwa go do tuby. Tym razem ruch wprowadzanego mazaka podnosi tubę nieco wyżej...

kolejno, jeden mazak za drugim, wylatują z tuby, potwierdzając wcześniejszą hipotezę dwójki dzieci. [...]

Satysfakcja jest wielka. Wysiłek i nieustępliwość Eriki zostają wynagrodzone.

Gra powtarzana jest z innymi mazakami... (Filipini, Giudici 2008: 11-15)7.

Z niezwykłą uwagą nauczyciele obserwowali dziecięce doświadczenie, o czym świadczy powyższa narracja. Dokumentowali i interpretowali ich strategie uczenia się, weryfikując swoje hipotezy, zadawali sobie pytania, jednocześnie stawiając kolejne hipotezy. Rezygnując ze swojego pomysłu (rysowanie mazakami), nauczyciele stworzyli inspirującą przestrzeń i dali dzieciom czas na eksplorowanie otaczającej je rzeczywistości. Nie byłoby to możliwe bez słuchania, bo tylko ono, jak akcentuje L. Malaguzzi (2012b), gwarantuje nam dorosłym opanowanie trudnej sztuki bycia z dziećmi, rozmawiania z nimi. Bez słuchania nauczyciele stracą bowiem

zaciekawienie, zachwyt, zadumę i radość z tego, że gdy tylko znajdziemy potrzebę i czas (o tak, czas też!), aby wkroczyć do dziecięcej zabawy i codziennej pracy dzieci, ich fakty i słowa rozprzestrzeniają się. To uczucia, bez których nie można pracować, są one tym, co posuwa do przodu nie tylko nasze codzienne

\footnotetext{
7 Narracja ta, jak i większość przytoczonych opisów, jest uzupełniona fotografiami. Niestety ze względu na prawa autorskie nie mam możliwości umieszczenia ich w tekście.
} 
myślenie, planowanie, naszą wyobraźnię, ale również refleksję nad naszą relacją z dziećmi (tamże: 339).

Przyjęcie perspektywy pedagogiki słuchania weryfikuje myślenie o roli nauczyciela. Nauczyciele w żłobkach RE odrzucają postawę dorosłego planującego dziecięcą aktywność, udzielającego wskazówek i narzucającego własne interpretacje rzeczywistości. Słuchając kompetentnego, pełnego potencjału dziecka, stają się jego partnerami w procesie konstruowania wiedzy i budują rusztowanie, które pomaga dziecku konstruować własne reprezentacje świata. Idea słuchania urzeczywistniona zostaje między innymi poprzez wykorzystanie $\mathrm{w}$ pracy $\mathrm{z}$ małym dzieckiem strategii projektowej, poprzez dokumentowanie dziecięcego procesu uczenia się oraz organizację inspirującej przestrzeni edukacyjnej. Te trzy wymiary zostaną szczegółowo opisane w dalszej części tekstu.

\section{Strategia projektowa w żłobku}

Opisując zadania nauczyciela w placówkach wczesnej edukacji w Reggio, L. Malaguzzi posługiwał się metaforą „nici Ariadny”. Nauczycieli postrzegał jako tych, którzy „trzymają nić, którzy konstruują i ustanawiają połączenia i związki, sieci relacji, aby przekształcić je w znaczące doświadczenie interakcji i komunikacji" (Rinaldi 2006: 54). W codziennej pracy taka postawa przejawia się przede wszystkim w dostarczaniu okazji do badania i odkrywania, w tworzeniu kontekstu, w którym dziecięce strategie uczenia się są respektowane, a teorie uprawomocnione. Ujawnia się ona w pracy metodą projektów, która w podejściu RE określana jest mianem progettazione (zob. Maj 2014). W tej strategii, wpisującej się w elastyczne podejście do programu, dziecięca aktywność nie jest wynikiem z góry zaplanowanych działań, ale wyłania się w toku wspólnej pracy dzieci i dorosłych. Jak słusznie puentuje Ronald Lally zajęcia „nie muszą być zaplanowane. Zamiast tego dziecięcy program uczenia się musi zostać odkryty, respektowany i wspierany" (2009: 70). Nauczyciel musi być uważny i posiadać zdolność dostrzegania potencjału w różnych, często spontanicznych sytuacjach, mających miejsce w żłobku. Tak było w przypadku wcześniej przywołanej przygody z mazakami i papierową tubą. Nauczyciele, gotowi do rezygnacji ze swoich propozycji, stworzyli dzieciom możliwość działania zgodnie ze swoim pomysłem i zainteresowaniem. Co więcej, takie doświadczenia stają się bardzo często dla nauczycieli Reggio inspiracją do zaaranżowania nowych kontekstów uczenia się, na przykład poprzez dostarczenie nowych materiałów do eksplorowania lub uczynienie kontekstów bardziej złożonymi (np. propozycja eksperymentowania z innymi przedmiotami, np. kulą, prostopadłościanem, plastikową tubą). Choć praca metodą projektów w żłobku może wydawać się bardzo trudna, to polega ona przede wszystkim na słuchaniu. Jak podkreśla Vea Vecchi (2010): 
Projekt otwarty na zmiany wywodzi się z uważnego „słuchania” rzeczywistości, dominują w nim sugestie pochodzące z obserwacji dzieci. Jeśli konkretne propozycje mają swój początek w zainteresowaniach dzieci i nauczycieli, istnieje znacznie większa szansa na ich sukces, ponieważ cała podróż jest nadzorowana i śledzona przez nauczyciela, który właściwie rozumie podstawowe jej właściwości, a w związku z tym jest jej bardziej ciekawy i zdolny do interweniowania i wprowadzania interesujących modyfikacji w trakcie jej trwania (tamże: 40).

Zadaniem nauczyciela jest więc wychwytywanie dziecięcych pomysłów, tak jak w przypadku projektu przywołanego przez Cristinę Bondavalli. Opisała ona historię 22-miesięcznego Alessandro, który przyniósł do żłobka jeżowca znalezionego nad morzem. Wśród dzieci wzbudziło to wiele emocji, pojawiły się pytania, potrzeba badania i eksperymentowania. Rozbudzona w dzieciach ciekawość została wsparta propozycją nauczycieli. W wyniku obserwacji i wspólnej dyskusji postanowili oni rozbudować kontekst zainicjowany przez chłopca. Przygotowali dzieciom szkła powiększające oraz lusterka o różnym powiększeniu po to, aby dzieci mogły dokładniej i z różnych perspektyw przyjrzeć się przyniesionemu jeżowcowi. Doświadczenie to stało się również okazją do eksperymentowania dzieci z językiem graficznym (Gandini 2001). Podchwycenie dziecięcych pomysłów ściśle wiąże się bowiem ze zorganizowaniem sytuacji, która umożliwi dzieciom dalsze eksplorowanie i badanie. Choć wydaje się to stosunkowo proste, to będąc skupionym na realizacji z góry ustalonego planu, istnieje duże ryzyko, że sytuacje mające w sobie potencjał badawczy zostaną przeoczone.

Pomysły na projekty wyłaniają się przede wszystkim z obserwacji danej grupy. Są też jednak takie propozycje nauczycieli, które, jak wynika z wieloletnich doświadczeń edukatorów RE, zwykle rozbudzają dziecięcą ciekawość i inspirują do eksplorowania. Należą do nich wszelkiego rodzaju zabawy ze światłem i cieniem. Nie oznacza to jednak konkretnych, szczegółowych scenariuszy zajęć. To raczej swoiste „prowokacje”, które mogą rozwinąć się w wielu, często nieprzewidzianych wcześniej przez nauczycieli, kierunkach. Ilustracją takich doświadczeń jest narracja „Granice światła”, opisana przez V. Vecchi (2010: 128-130).

Samuele i Camilla (2 lata i 11 miesięcy) zatrzymali się, aby obserwować cienie, powstałe dzięki papierowym wzorom, umieszczonym na szybie (ryc. 1a).

SAMUELE: To słońce je robi. One są pokolorowane na biało.

CAMILLA: Tutaj cień jest trochę ciemniejszy.

SAMUELE: Patrz to rysowanie w świetle. Widzisz, światło jest całe w środku i pozostaje nieruchome (tamże: 128). (ryc. 1a) 


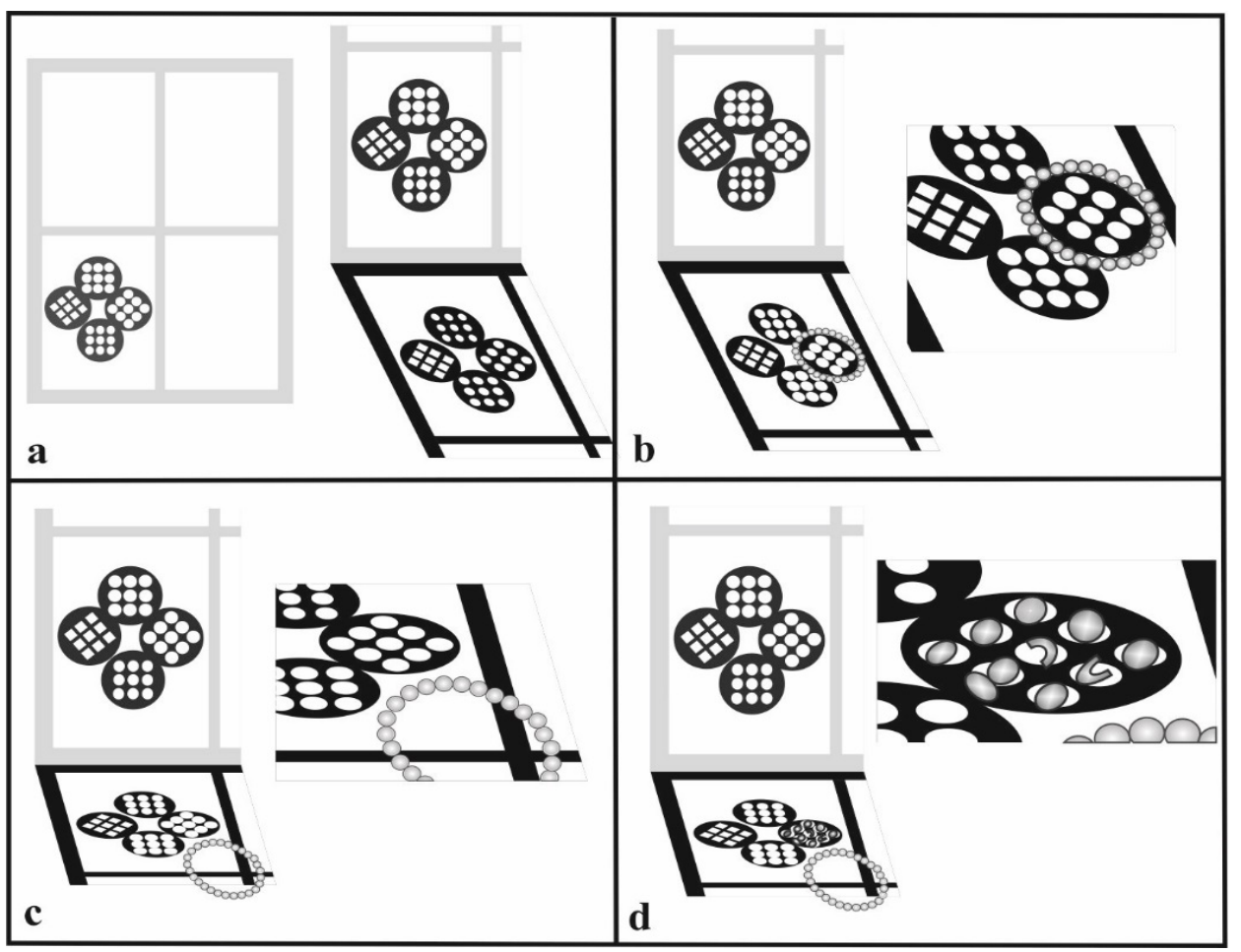

Ryc. 1. Szkice ilustrujące mini opowieść „Granice światła”

Źródło: opracowanie własne na podstawie dokumentacji zdjęciowej (Vecchi 2010: 128)

Samuel wiedział, że fascynujące wzory na podłodze powstały dzięki słońcu, że stworzyły je razem: światło i cień. Interpretując ten dialog, V. Vecchi zauważyła, że dzieci, będąc świadomymi różnych odcieni światła i cieni (nie tylko bieli i czerni), słusznie nazwały wzory kolorowymi. Według niej stworzyły niezwykle poetycką definicję cienia - „rysowanie światłem” (tamże).

Nauczycielka, dostrzegając w dziecięcej rozmowie potencjał, postanowiła zainterweniować:

To „rysowanie światłem jest naprawdę piękne! Czy uda nam się zatrzymać cień z nami, tutaj w żłobku? Czy zdołamy zatrzymać go na podłodze, tam gdzie jest teraz? (tamże: 129).

Aby zwrócić uwagę dzieci na poruszanie się cienia, nauczycielka zaproponowała dzieciom, aby spróbowały unieruchomić cień. Uznała, że takie działanie może wzbudzić ciekawość i zainspirować nowe dziecięce pytania. Dzieci z dostępnych materiałów wybrały przezroczyste szklane koraliki w różnych kolorach. 
SAMUELE: Wybieram te, ponieważ mają w sobie światło.

CAMILLA: Ja wybieram te, ponieważ mają małe dziurki w środku i światło przechodzi przez nie. Myślę, że zapalą się światłem (tamże: 129).

Dzieci ułożyły kamyki dookoła wzoru utworzonego przez cień, tworząc okrąg (ryc. 1b).

SAMUEL: Dokładnie zamykam okrąg, aby cień się nie wydostał (tamże).

Ponieważ nadeszła pora obiadu, dzieci musiały przerwać pracę. Po powrocie sprawdziły, co zadziało się z cieniami.

To niegrzeczny cień. Ucieka od kamieni. Spójrz cień się ruszył, bo słońce się rusza (tamże). (ryc. 1c)

Pomimo że Samuele od początku był świadomy, że cień powstaje dzięki słońcu, to nie do końca był pewien, co przyczyniło się do zmiany jego położenia. Postanowił podjąć kolejną próbą i pobawić się wspólnie z innymi dziećmi. Dzieci wybrały transparentne obiekty i umieściły je w jasnych częściach wzoru (ryc. 1d).

CAMILLA: Położymy te większe kulki na światło (tamże).

Z uwagą i zaangażowaniem dzieci umieszczały szklane kulki w jasnej przestrzeni. Kształt cienia oraz transparentne przedmioty wzmocnione przez światło stworzyły dla dzieci interesującą kompozycję, odciągając ich uwagę od początkowego problemu przemieszczania się cienia. Skupiły się na estetycznej stronie swojej kompozycji.

SAMUELE: Patrzcie to rysowanie światłem (tamże: 130).

Nauczyciel nie interweniował i nie nalegał na powrót do pierwotnych pytań. Taka sytuacja dla nauczyciela w Reggio jest okazją do zaproponowania nowych zadań, nowego przedmiotu dziecięcych dociekań. Nauczycielka zrezygnowała ze swojego pomysłu i pozwoliła, aby aktywność dzieci była wynikiem ich zainteresowania, a nie z góry narzuconego scenariusza.

Dylemat, kiedy reagować, kiedy pomóc dziecku w rozwiązywaniu problemu, wskazać kierunek jego aktywności, jest jednym z najtrudniejszych aspektów pracy metodą projektów. Wymaga od nauczyciela nieustannego balansowania. Zbyt częste ingerowanie w dziecięcy proces uczenia się może go zahamować, z drugiej zaś strony nauczyciel powinien organizować takie sytuacje edukacyjne, które postawią przed dziećmi zadania wymagające wysiłku i będące dla nich wyzwaniem (Edwards 2012). Narzędziem ułatwiającym podejmowanie decyzji jest dokumentacja, która w podejściu RE nabrała swoistego znaczenia. 


\section{Dokumentacja jako wizualizacja słuchania}

Słuchanie i reagowanie w optymalnym dla dziecięcego procesu uczenia się czasie jest kluczowym zadaniem nauczyciela pracującego metodą projektów. Na podstawie wnikliwej obserwacji, dokumentacji oraz wspólnej refleksji z innymi edukatorami pracującymi w żłobku, nauczyciel podejmuje decyzje odnośnie do nowych kontekstów uczenia się. C. Rinaldi interpretuje dokumentację "jako uwidocznienie procesu słuchania, jako konstrukcje śladów (poprzez notatki, slajdy, filmy), które nie tylko są dowodem dziecięcych ścieżek procesu [uczenia się - przyp. A.M.], ale które umożliwiają im również tworzenie relacji, które są podstawą wiedzy (Rinaldi 2008: 8). Charakterystyczną dla żłobków RE formą dokumentacji są wspomniane wcześniej pamiętniki, będące zapisem doświadczeń poszczególnych dzieci w relacji $\mathrm{z}$ rówieśnikami, dorosłymi, a także z przestrzenią, w której funkcjonują. Koncepcja pamiętników, osadzona w dyskursie nadawania znaczeń (Dahlberg i in. 2013), ukazuje złożoność i wieloaspektowość dziecięcego procesu konstruowania wiedzy. Na ten aspekt zwraca uwagę C. Rinaldi (2009):

Podejściu edukacyjnemu wyłaniającemu się z tych pamiętników bardzo daleko do koncepcji laboratorium, czyli takiej formy środowiska, w której możliwe jest wyizolowanie zmiennych zależnych i niezależnych. W tym sensie pamiętniki były ekologiczne, otwarte na nieustanną zmianę warunków i na uchwycenie sytuacji w całym jej bogactwie i złożoności (tamże: 13).

Tak interpretowane pamiętniki stoją w opozycji do zakorzenionego w tradycji anglosaskiej portfolio, w którym dominuje język standardów i odpowiedzialności za ich realizację (zob. Maj 2013). „Czas pamiętnika jest czasem wolniejszym: to czas refleksyjności, przerw, wewnętrznego słuchania. To czas wspomnień" (tamże: 1415). Takie podejście bez wątpienia sprzyja relacjom, byciu razem z dzieckiem i na dziecko uważnym.

\section{Organizacja przestrzeni jako stymulowanie procesu uczenia się}

Niezwykle ważnym zadaniem nauczyciela RE jest organizacja przestrzeni edukacyjnej dziecka. Według L. Malaguzziego środowisko jest to „integralna część projektu edukacyjnego, która odgrywa decydującą rolę we współistnieniu, w spójności i intensywności reakcji na potrzebę bycia i działania dzieci oraz pracowników (Cagliari i in. 2016: 235). Ma ona zachęcać do dialogu, inspirować społeczne interakcje, rozbudzać dziecięcą ciekawość oraz sprzyjać eksplorowaniu i badaniu. Organizację przestrzeni w żłobku ilustruje rycina 2. 


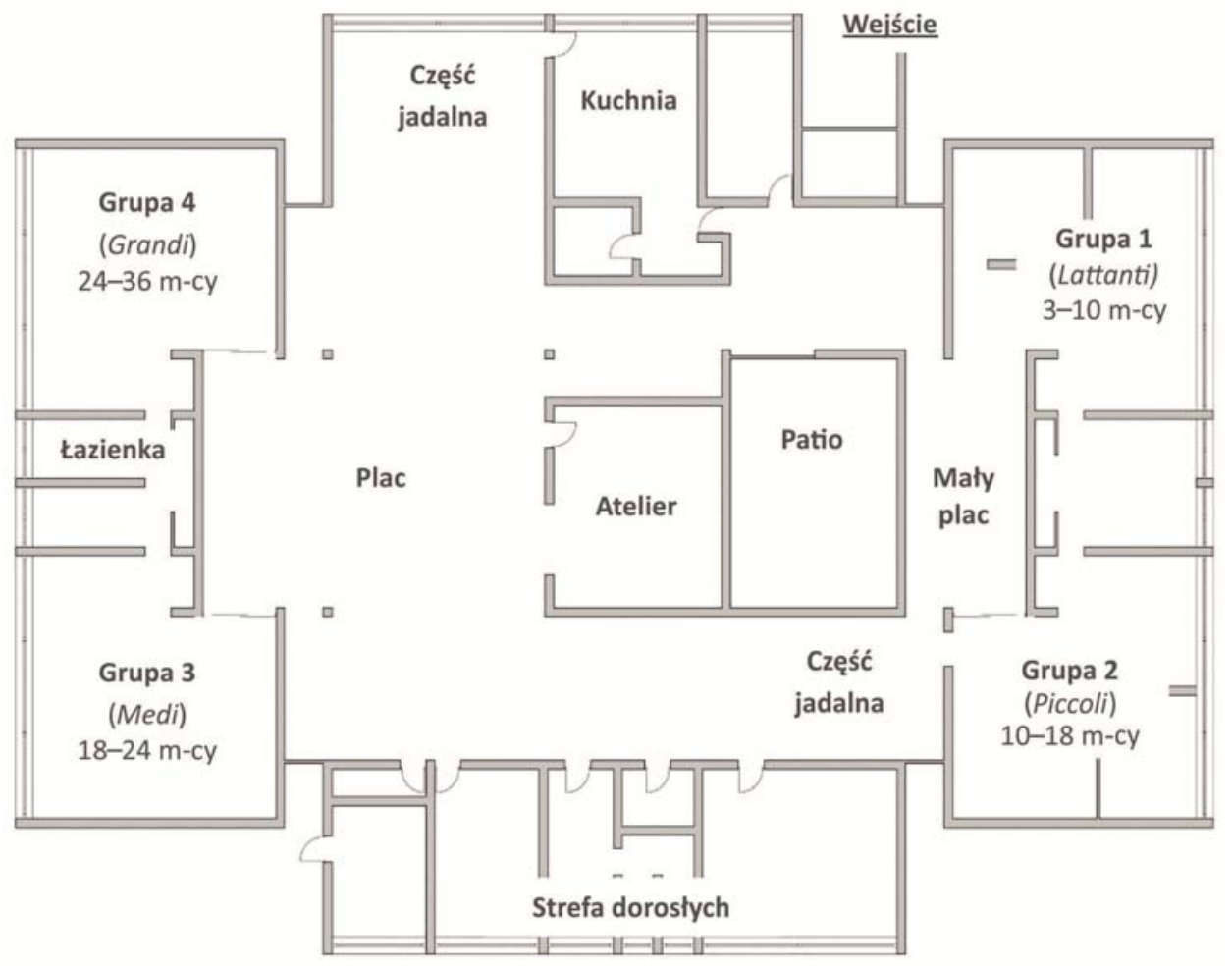

Ryc. 2. Plan żłobka Panda

Źródło: opracowanie A. Kruhelska i A. Maj na podstawie „Nido d’infanzia Panda. Tracce di identita" - ulotka ze żłobka Panda

Centralnym miejscem w żłobku jest plac wykorzystywany do grupowych zabaw, różnorodnych uroczystości czy spotkań z rodzicami. Tuż obok znajduje się atelier $^{8}$ będące swoistą pracownią plastyczną, wyposażoną w najróżniejsze materiały stymulujące dziecięcy proces uczenia się (część z tych materiałów znajduje się również w salach). Wśród nich znaleźć można m.in. różnego rodzaju farby, papiery, skrawki materiałów, folie, materiały naturalne: kasztany, liście, kamienie oraz szereg innych produktów, które umożliwiają dzieciom wyrażanie swoich myśli

\footnotetext{
${ }^{8}$ Gospodarzem atelier jest atelierista, osoba z wykształceniem w zakresie sztuk wizualnych, niestety ze względu na wyższe koszty utrzymania żłobków atelieristi zatrudniani są tylko w przedszkolach Reggio. Pomimo to nauczyciele pracujący w żłobkach korzystają z ich doświadczeń. Jest to efekt organizacji, w której podstawą jest kolegialny wymiar pracy. W każdej placówce funkcjonuje pedagogista, który pełni w żłobkach i przedszkolach rolę doradcy (nie ma dyrektora), jednocześnie nadzorując pracę w kilku placówkach (np. 2 żłobkach i 4 przedszkolach). Jest odpowiedzialny za zapewnienie spójnego programu edukacyjnego, integruje i koordynuje administracyjne i pedagogiczne aspekty ich funkcjonowania. Organizuje spotkania nauczycieli, których celem jest namysł i refleksja nad codziennością edukacyjną. Są one okazją do dialogu i wymiany doświadczeń. Narzędziem wykorzystywanym w tym procesie jest bogata dokumentacja, przygotowywana w każdej placówce (zob. Maj 2011).
} 
w różnorodnych formach. Niezwykłym ze względu na właściwości materiałem, wykorzystywanym na co dzień w placówkach Reggio, jest glina, z którą dzieci oswajają się już w żłobku. Zadaniem atelier jest inspirowanie dzieci i nauczycieli do używania wielu różnorodnych języków. Obok atelier znajduje się patio - wewnętrzny ogród. Dzięki szklanym ścianom, które dostarczają naturalnego światła, dzieci mają okazję eksperymentować ze światłem i cieniem.

Wokół placu rozlokowane są sale ${ }^{9}$. Pomimo że dzieci podzielone są na grupy, mają możliwość swobodnego przemieszczania się i kontaktu z rówieśnikami (część przestrzeni jest wspólna, jak np. łazienka lub część jadalni). Każda z sal dostosowana jest do wieku i potrzeb dzieci. Jej organizacja i wyposażenie ulegają modyfikacji w zależności od dziecięcych zainteresowań. Tak zorganizowana przestrzeń stwarza warunki do wspólnego negocjowania znaczeń. Jak podkreśla V. Vecchi, dziecko ma prawo do pięknego i zdrowego otoczenia, środowisko jest bowiem „oknem dla pomysłów" (Vecchi 2010: 82).

\section{Zakończenie}

Podejście edukacyjne RE jest koncepcją pracy w żłobku, która opiera się na dialogu pomiędzy dzieckiem a nauczycielem. Osadzone w socjokulturowej teorii uczenia się akcentuje znaczenie interakcji społecznych $\mathrm{w}$ dziecięcym procesie uczenia się. Nauczyciel pełni rolę „podajnika” okazji, jest źródłem inspiracji oraz organizuje przestrzeń edukacyjną dziecka (Edwards 2012). Wsłuchując się w jego potrzeby i zainteresowania, staje się jego partnerem w konstruowaniu dziecięcych reprezentacji świata.

\section{Bibliografia}

Cadwell L. B. (2003) Bringing Learning to Life. The Reggio Approach to Early Childhood Education, New York, Teachers College Press.

Cagliari P., Castagnetti M., Giudici C., Rinaldi C., Vecchi V., Moss P. (red.) (2016) Loris Malaguzzi and the Schools of Reggio Emilia. A selection of his writings and speeches, 1945-1993, London, Routledge.

\footnotetext{
9 Do żłobka Panda uczęszcza 70 dzieci podzielonych na 4 grupy:

I - 12 dzieci w wieku 3-9 m-cy, 2 nauczycieli;

II - 14 dzieci w wieku 10-17 m-cy, 2 nauczycieli + 1 pracujący w grupie I i II;

III - 20 dzieci w wieku 18-24 m-ce, 3 nauczycieli;

IV - 24 dzieci w wieku 24-36 m-cy, 3 nauczycieli.

Dodatkowo kadrę żłobka stanowią: 1 nauczyciel na pół etatu, pedagogista (pedagog mający pod swoją opieką kilka placówek), 1 kucharka + 3 pomoce na pełen etat, 3 pracowników obsługi na pół etatu.
} 
Dahlberg G., Moss P., Pence A. (2013) Poza dyskursem jakości w instytucjach wczesnej edukacji i opieki, tłum. K. Gawlicz, Wrocław, Wydawnictwo Naukowe DSW.

Edwards C. (2012) Teacher and Learner, Partner and Guide: The Role of the Teacher w: The Hundred Languages of Children. The Reggio Emilia Experience in Transformation, C. Edwards, G. Forman, L. Gandini (red.), Santa Barbara, Praeger, s. 147-172.

Edwards C., Rinaldi C. (red.) (2009) The Diary of Laura. Perspectives on a Reggio Emilia Diary, St. Paul, Readleaf Press.

Filipini T., Giudici C. (2008) Contagious Experiments w: Making Learning Visible: Children as Individual and Group Learners, C. Giudici, M. Krechevsky, C. Rinaldi (red.), Reggio Emilia, Reggio Children srl., s. 10-15.

Gandini L. (2001) Reggio Emilia: Experiencing Life in an Infant-Toddler Center. Interview with Cristina Bondavalli w: The Italian Approach to Infant/Toddler Care, L. Gandini, C. P. Edwards (red.), New York, Teacher Collage Press, s. 55-67.

Gandini L. (2012) History, Ideas, and Basic Principles: An Interview with Loris Malaguzzi w: The Hundred Languages of Children. The Reggio Emilia Experience in Transformation, C. Edwards, G. Forman, L. Gandini (red.), Santa Barbara, Praeger, s. 27-71.

Hall K., Horgan M., Ridgway A., Murphy R., Cunneen M., Cunningham D. (2010) Loris Malaguzzi and the Reggio Emilia Experience, London, Continuum Library of Educational Thought, vol. 23.

Karwowska-Struczyk M. (2012) Edukacja przedszkolna. W poszukiwaniu innych rozwiq̨zań, Warszawa, Wydawnictwo UW.

Lailly J. R. (2009) How the Infant Teacher's Context Influences the Content of Diaries w: The Diary of Laura. Perspectives on a Reggio Emilia Diary, C. Edwards, C. Rinaldi (red.), St. Paul, Readleaf Press, s. 67-75.

Maj A. (2011) Rozwój zawodowy nauczycieli przedszkoli w Reggio Emilia we Włoszech w: Nauczyciel wczesnej edukacji. Oczekiwania społeczne i praktyka edukacyjna, J. Bonar (red.), Łódź, Wydawnictwo UŁ, s. 79-89.

Maj A. (2014), Metoda projektów we wczesnej edukacji szansq demokratyzacji przestrzeni edukacyjnej dziecka w: Demokracja i edukacja: dylematy, diagnozy, doświadczenia, K. Gawlicz, P. Rudnicki, M. Starnawski, T. Tokarz (red.), Wrocław, Wydawnictwo Naukowe DSW.

Maj A. (2016) Podejście Reggio Emilia jako doświadczenie edukacyjne oparte na partycypacji. O możliwym w przedszkolu przymierzu nauczycieli i rodziców, „Edukacja Elementarna w Teorii i Praktyce", nr 2, s. 111-129.

Maj A. (2017) Koncepcja stu języków dziecka w przedszkolach Reggio Emilia. O przełamaniu hegemonii języka werbalnego w dziecięcym procesie uczenia się, „Problemy Wczesnej Edukacji", nr 1 (36), s. 112-120. 
Malaguzzi L. (2012a) Speech to a conference 'Quale future per l'asilo nido', Turin, December 1986, P. Cagliari, M. Castagnetti, C. Giudici, C. Rinaldi, V. Vecchi, P. Moss (red.), London, Routledge, s. 315-318.

Malaguzzi L. (2012b) 91.88 Article in ALFABATIERE'88', a booklet produced by Scuola communale dell'infanzia Diana, P. Cagliari, M. Castagnetti, C. Giudici, C. Rinaldi, V. Vecchi, P. Moss (red.), London, Routledge, s. 338-340.

Moss P. (2012a) Early years. To 1963. Introduction w: Loris Malaguzzi and the Schools of Reggio Emilia. A selection of his writings and speeches, 1945-1993, P. Cagliari, M. Castagnetti, C. Giudici, C. Rinaldi, V. Vecchi, P. Moss (red.), London, Routledge, s. 3-16.

Rinaldi C. (2001) Reggio Emilia: The Image of the Child and Child's Environment as Fundamental Principle w: The Italian Approach to Infant/Toddler Care, L. Gandini, C. P. Edwards (red.), New York, Teacher Collage Press, s. 49-54.

Rinaldi C. (2006) In Dialogue with Reggio Emilia. Listening, Researching and Learning, London, Routledge.

Rinaldi C. (2008) Documentation and Assessment: What Is the Relationship? w: Making Learning Visible: Children as Individual and Group Learners, C. Giudici, M. Krechevsky, C. Rinaldi (red.), Reggio Emilia, Reggio Children srl., s. 78-89.

Rinaldi C. (2009) Reinventing Laura. An educational diary in a Reggio Emilia nido w: The Diary of Laura. Perspectives on a Reggio Emilia Diary, C. Edwards, C. Rinaldi (red.), St. Paul, Readleaf Press, s. 9-15.

Szczepska-Pustkowska M. (2013) Sto języków dziecka: wczesna edukacja z inspiracji myślq pedagogicznq Lorisa Malaguzzi, „Problemy Wczesnej Edukacji”, nr 1 (20), s. 76-91.

The Charter of the City and Childhood Councils, Reggio Children srl., Reggio Emilia 2002.

The Diary at the Infant-toddler Center to Record Stories of Children Story of Laura (2009) w: The Diary of Laura. Perspectives on a Reggio Emilia Diary, C. Edwards, C. Rinaldi (red.), St. Paul, Readleaf Press, s. 18-53.

The Infant-toddler Centers and Preschols of Reggio Emilia. Historical Notes and General Information (2010), Preschools and Infant-toddler Centers Istituzione of the Municipality of Reggio Emilia and Reggio Children.

Vecchi V. (2010) Art and Creativity in Reggio Emilia, London, Routledge.

\section{Netografia}

Reggio Emilia Approach http://www.reggiochildren.it/identita/reggio-emilia-approach/ ?lang=en [dostęp 26.04.2017]. 